\title{
Trigone ventricular meningiomas - clinical characteristics, histopathology and results of surgical treatment
}

\author{
Kamil Leśniewski ${ }^{1}$, Przemysław Kunert ${ }^{1}$, Ewa Matyja ${ }^{2}$, Tomasz Czernicki ${ }^{1}$, \\ Katarzyna Wójtowicz ${ }^{1}$, Jakub Wojciechowski ${ }^{1}$, Andrzej Marchel ${ }^{1}$ \\ ${ }^{1}$ Department of Neurosurgery, Medical University of Warsaw, Poland \\ ${ }^{2}$ Department of Experimental and Clinical Neuropathology, Mossakowski Medical Research Centre, \\ Polish Academy of Sciences, Warsaw, Poland
}

\begin{abstract}
Aim of the study. Intraventricular meningiomas (IVMs) are rare tumours accounting for $0.5-3.0 \%$ of all meningiomas. IVMs require different surgical approaches and preparation in deep brain areas. The aim of our study was to present the clinico-histopathological characteristics and treatment outcomes of trigone IVMs in a series of 15 patients.

Materials and methods. Eight women and seven men (mean age 52) with 15 trigone IVMs were retrospectively analysed. Patients presented with headache $(47 \%)$, psychoorganic syndrome $(40 \%)$, hemianopsia $(33 \%)$ or paresis $(20 \%)$, including three (20\%) patients with Karnofsky Performance Scale (KPS) < 80. Mean tumour size was $55.2 \mathrm{~mm}$ (range: 30-100 mm).

Results. Gross total tumour resection was performed in 14 (93\%) cases, and subtotal in one (7\%). A new deficit appeared in $83 \%$ (5/6) following a transparietal approach, in 14\% (1/7) following a transtemporal approach, and in none of two patients following a transoccipital approach. Postoperative complications occurred in six (40\%) patients; no patient died, but in two (13\%) the new deficit was permanent. Tumour re-growth was found in two (13\%) patients after 14 and 31 months. Meningiomas of WHO grade I occurred in 12, grade II in three, and grade III in one tumour recurrence. In long-term follow-up (mean: 60.8 months), including the results of revision operations, KPS: 80-100 was in 13 (87\%) patients, KPS: 50 in one (severe hemiparesis after revision) and one patient was lost to follow-up (KPS: 100 on discharge).
\end{abstract}

Conclusions. $20 \%$ of IVMs in our series were atypical. The results of surgery for IVMs, although satisfactory in general, require further improvement by reducing the rate of focal deficits resulting from a surgical approach.

Key words: Intraventricular meningioma, surgical approach, morbidity, tumour recurrence (Neurol Neurochir Pol 2019; 53 (1): 34-42)

\section{Introduction}

Intraventricular meningiomas (IVMs) are rare tumours accounting for $0.5-3.0 \%$ of all meningiomas. Their distinguishing feature is the lack of a dural attachment. IVMs require different surgical approaches and preparation in the vicinity of the central area of the brain. The first description of an intraventricular tumour with the morphology of a meningioma was presented by Shaw in 1854 [1] and MacDowell was the first to treat it surgically in 1881 [2]. In 1938, Cushing and Eisenhardt described three cases of intraventricular tumours in a group of 313 patients operated on for meningiomas, including the first case of a third ventricular meningioma [3]. Recently, Pereira et al. systematically reviewed 682 IVMs from 98 papers [4].

The aim of this study was to present the clinical and histopathological characteristics of trigone IVMs based on our series of 15 patients. The results of surgical treatment together with an analysis of postoperative complications are also presented. The study rationale is the rarity of IVMs and the need to accumulate published data about their clinical course and treatment. 


\section{Material and methods}

A series of 15 consecutive patients operated on for trigone IVM from 1988 to 2016 were subjected to retrospective analysis. The information was obtained from patient hospital files, outpatient cards, radiological archives and histopathological archives. The 15 patients comprised eight (53\%) women and seven (47\%) men aged from 22 to 78 years (mean age 52). Only a CT scan with contrast was performed on the first three $(20 \%)$ patients of the analysed period, and twophase MR imaging was employed in the remaining 12 cases. In two cases, cerebral digital subtraction angiography was also performed.

\section{Surgical treatment}

A transgyral approach was used in all cases, including a posterior temporal lobe approach in seven cases, a superior parietal lobule approach in six cases, and an occipital approach via the lateral ventricle posterior horn in two cases. The occipital approach was employed only in patients with already existing contralateral hemianopsia.

For tumours located in the dominant hemisphere, approaches through the superior parietal lobule (four cases), inferior temporal gyrus (two cases), or through the occipital lobe (one case) were used. Tumours in the non-dominant hemisphere were approached via the posterior middle temporal gyrus (five cases), via the upper parietal lobule (two cases) or through the occipital lobe (one case). Intraoperative neurophysiological monitoring and neuronavigation were not used. Gross total tumour resection was performed in 14 (93\%) cases, and subtotal resection in one (7\%) case.

\section{Postoperative management}

After the procedure, the patients were awakened and monitored over the first hours in the postoperative ward. Rehabilitation commenced on the first postoperative day and the patient was encouraged to attempt an upright position and ambulate on the second postoperative day. Two-phase CT scans were routinely performed to exclude clinically significant tumour residues and other adverse effects of the operation.

\section{Postoperative evaluation}

A postoperative course with complications was defined as the occurrence of at least one adverse event, including (1) the occurrence of, or an increase in, neurological deficit, (2) abnormal results of postoperative CT scan (pneumo-, hydrocephalus, intracranial bleeding, oedema or stroke) resulting in the need for separate management, (3) liquorrhea, (4) poor wound healing, and (5) systemic complications. The short-term outcome was assessed on the day of discharge using the Glasgow Outcome Scale [5] and the Karnofsky Performance Scale (KPS) [6]. The KPS was used to evaluate the long-term outcome. Data from the last outpatient visit was used for long-term evaluation. The risk of tumour recurrence was assessed based on the last follow-up MR imaging. Follow-up data was obtained in 14 (93\%) patients, with a mean follow-up period of 5.1 years.

\section{Histopathology}

For the purposes of this study, due to the long analysed period (28 years), tumour specimens were subjected to histopathological verification to unify the nomenclature and grading according to the $2007 \mathrm{WHO}$ central nervous system tumour classification.

\section{Results}

\section{Signs and symptoms}

The duration of symptoms ranged from 0.5 to 47 months (mean 7 months). Headaches were the most common reason for neuroimaging (47\%). Psychoorganic syndrome was presented by $40 \%$ of the patients, and hemianopsia was found in 33\% (Tab. 1 and Tab. 6). In one case, an asymptomatic tumour with a diameter of $66 \mathrm{~mm}$ was diagnosed incidentally after a head injury. Three (20\%) patients presented with a KPS of less than 80 on admission (Tab. 2).

Dilatation of the ventricular system or the trapped ventricle in pre-operative imaging was found in $11(73 \%)$ patients, including $5 / 7$ with a history of headaches and $6 / 8$ without a history of headaches.

\section{Tumour characteristics}

In seven (47\%) of the 15 cases, the trigone lateral ventricular tumours were located on the left side, and in the other eight (53\%) on the right side. Tumour size ranged from 30 to $100 \mathrm{~mm}$ (mean 55.2). Calcifications in the tumour mass in the CT images were found in six (46\%) cases out of 13 patients for whom such a study was performed. Thirteen (87\%) tumours demonstrated homogenous enhancement after contrast

Table 1. Signs and symptoms

\begin{tabular}{lc}
\multicolumn{1}{c}{ Signs and symptoms } & Number (\%) \\
Headaches & $7(47 \%)$ \\
Mental disturbances & $6(40 \%)$ \\
Hemianopsia & $5(33 \%)$ \\
Papilledema & $3(20 \%)$ \\
Hemiparesis & $3(20 \%)$ \\
Gait disturbances & $1(7 \%)$ \\
Hemiaesthesia & $2(13 \%)$ \\
Aphasia & $2(13 \%)$ \\
Epilepsy & $1(7 \%)$ \\
Accidental diagnostics & $1(7 \%)$ \\
(asymptomatic tumour) &
\end{tabular}


Table 2. Condition of patients before surgery, at discharge, at 6-month follow-up, and the final accessible outcome according to the Karnofsky Performance Scale (KPS)

\begin{tabular}{lccccccc}
\multicolumn{2}{c}{ Before surgery } & \multicolumn{2}{c}{ At discharge } & \multicolumn{2}{c}{ 6-mth follow-up } & \multicolumn{2}{c}{ The final outcome* } \\
\hline KPS & No (\%) & KPS & No (\%) & KPS & No (\%) & KPS & No (\%) \\
100 & $3(20 \%)$ & 100 & $8(53 \%)$ & 100 & $12(86 \%)$ & 100 & $12(80 \%)^{* *}$ \\
90 & $7(47 \%)$ & 90 & $3(20 \%)$ & 90 & $1(7 \%)$ & 90 & $2(13 \%)$ \\
80 & $2(13 \%)$ & 80 & $2(13 \%)$ & 80 & $1(7 \%)$ & 80 & 0 \\
70 & $2(13 \%)$ & 70 & $2(13 \%)$ & 70 & 0 & 70 & 0 \\
60 & $1(7 \%)$ & 60 & 0 & 60 & 0 & 60 & 0 \\
50 & 0 & 50 & 0 & 50 & 0 & 50 & $1(7 \%)^{* * *}$
\end{tabular}

*Including results of revision operations and the last accessible data; **One patient lost to follow-up following surgery; the short-term outcome is included here; ***This patient was lost to further follow-up following revision surgery; the short-term outcome following the second operation is included here
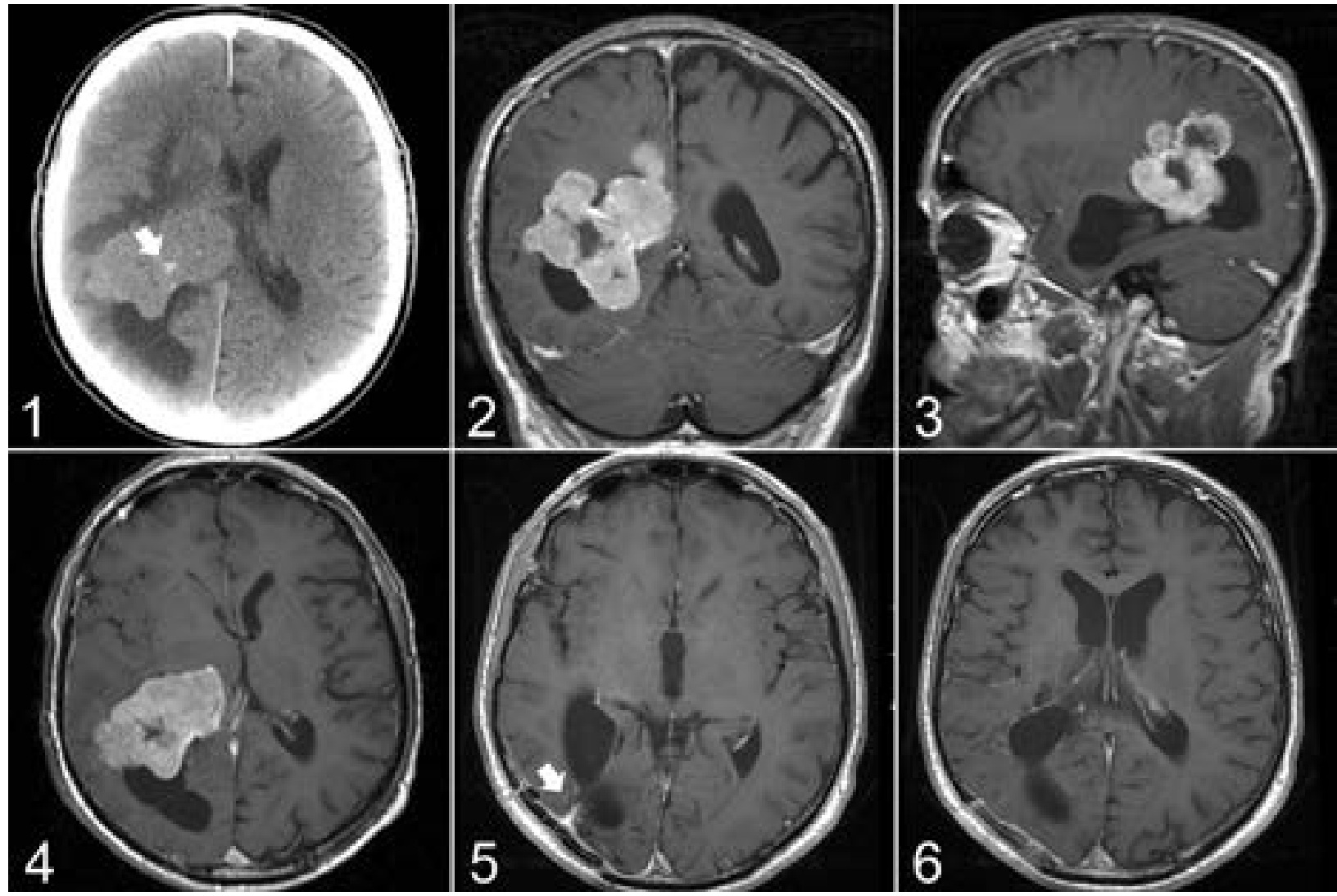

Figure 1.1. Preoperative, non-contrast CT showing a large isodense pathological mass with calcifications (arrow) in the right ventricular trigone with brain oedema surrounding; Figure 1.2-1.4. Preoperative, T1-weighted MR images demonstrating well-circumscribed polycyclic tumour, with non-homogeneous post-contrast enhancement; Figure 1.5-1.6. Follow-up MRI, obtained one year post-surgery, revealed no tumour re-growth. A corridor after transoccipital approach is visible (arrow)

administration (Fig. 1). There were no cases of intra-tumour cysts or haemorrhage into or out of the tumour. Cerebral angiography was performed in two patients with lateral ventricular tumours; in both cases, the vascular supply came from the anterior and posterior choroidal arteries.
Short-term outcomes

On the day of discharge, according to the GOS, a good recovery was achieved in $12(80 \%)$ patients and mild disability in three $(20 \%)$ patients. Thirteen $(87 \%)$ patients were discharged from the hospital as being independent and able to lead 
Table 3. Histopathology of intraventricular meningiomas

$\begin{array}{lr}\text { Histopathology subtype } & \text { No (\%) } \\ \text { Transitional m. (WHO G I) } & 6(40 \%) \\ \text { Fibroblastic m. (WHO G I) } & 5(33 \%) \\ \text { Angiomatous m. (WHO G I) } & 1(7 \%) \\ \text { Atypical m. (WHO G II) } & 3(20 \%)^{*}\end{array}$

$\mathrm{G}$ - grade; $\mathrm{m}$. — meningioma; *One of the atypical meningiomas re-grew and transformed to anaplastic form (WHO G III)

a normal life (KPS 80-100). Two patients had mild hemiparesis but were able to walk (KPS 70) (Tab. 2).

\section{Histopathology}

Meningiomas WHO grade I occurred in 13 patients and WHO grade II in three patients. One tumour re-grew as a WHO grade III (Tab. 3). The WHO grade I meningiomas included six transitional subtypes (Fig. 2.1), five fibroblastic subtypes (Fig. 2.2) and one angiomatous subtype. Among the transitional meningiomas, some tumours exhibited a heterogenous pattern combined with angiomatous (one patient) and metaplastic/xanthomatous (one patient) areas. One fibroblastic meningioma presented a combined pattern with a transitional component. Three tumours with sheeting architecture, hypercellularity neoplastic cells with prominent nucleoli and mitotic figures were recognised as atypical meningiomas WHO grade II. They contained numerous small foci of spontaneous necrosis with peripheral pseudopalisading (Fig. 2.3) and foci of foamy (xanthomatous) cells (Fig. 2.4). Moreover, one recurrence of atypical meningioma appeared to be anaplastic WHO grade III (Fig. 2.5). This exhibited large areas of necrosis, marked cellular pleomorphism, and increased mitotic count that exceeded 20 mitoses per $10 \mathrm{HPFs}$ (high-power fields). The neoplasm extensively invaded the brain parenchyma and was accompanied by a severe reaction of astroglial cells (Fig. 2.6).

\section{Postoperative complications}

No patient died in the perioperative period. However, the postoperative course was complicated in six (40\%) patients (Tab. 4). Three patients (43\%) after a left-sided approach, and three (38\%) after a right-sided approach, demonstrated neurological sequelae of the surgery. A new or worsening of a pre-existing neurological deficit was most often found following a superior parietal lobule approach, i.e. in 5/6 (83\%) cases (Tab. 5 and Tab. $6)$. In addition, in one case in this group, the procedure was complicated by a haematoma requiring reoperation, followed by liquorrhea treated with external CSF drainage. 1/7 (14\%) patients, following a transtemporal approach, demonstrated transient confusion with confabulations associated with a local brain oedema. There was neither clinically significant hydrocephalus nor pneumocephalus in our series. Deep vein thrombosis in the lower extremities occurred in one (7\%) patient.

\section{Tumour recurrence}

Tumour re-growth was found in two (13\%) patients at 14 and 31 months after the first operation (average of 23 months). In both patients, the tumour was removed completely during the first surgery via the parietal lobule approach and the lower temporal gyrus approach. Both patients underwent revision surgery and, using the same surgical approaches as before, the tumours were completely removed. In the first patient, atypical meningioma was diagnosed (WHO grade II) after the first operation (patient $\mathrm{N}^{\circ} 5$ in Tab. 6). Then the patient underwent supplementary fractioned radiotherapy with a dose of 5,600 cGy. After revision surgery, the patient was discharged from hospital with severe hemiparesis and hypoaesthesia (GOS = SD, KPS 50). A histopathological examination revealed an anaplastic meningioma (WHO grade III). In the second patient, a transitional meningioma (WHO grade I) was diagnosed following both the first and the revision surgery (patient $\mathrm{N}^{\circ} 6$ in Tab. 6). After reoperation, the patient was discharged home with a satisfactory outcome (KPS 90, GOS $=\mathrm{MD}$ ), and with a minor cognitive impairment.

No tumour progression was observed during the follow-up period of 12 years in the only patient following subtotal tumour resection. A tumour remnant of approximately $5 \mathrm{~mm}$ on the choroid vein was left in this case. No supplementary treatment was applied. A histopathological examination showed a transitional meningioma of WHO grade I.

\section{Long-term outcomes}

Follow-up data was available from 0.5 to 20.3 years (mean 5.1 years) after surgery in 14 patients. The only patient who was lost to follow-up was discharged home in good condition, with no neurological deficits (KPS 100). At six months follow-up, all remaining 14 patients could lead a normal life (KPS 80-100) (Tab. 2). Neurological deficit persisted in two patients (13\%), including slight hemiparesis and hemianopsia (KPS 80) in one patient and partial alexia (KPS 90) in the other patient. The preoperative hemianopsia significantly subsided in both patients operated on via the occipital lobe. In the long-term assessment, including the results of revision operations, normal life activity (KPS 90-100) could be conducted by 13/14 (93\%) patients. One patient was discharged from hospital after re-operation with severe hemiparesis (GOS = SD, KPS 50) and was lost to further follow-up.

\section{Discussion}

Intraventricular meningiomas account for $0.5-3.0 \%$ of intracranial meningiomas $[3,7-9]$ with a relatively higher appearance rate in children $[8,10,11]$. It is commonly considered that their origin is arachnoid cells in the mesenchymal stroma of the choroid plexus or the tela choroidea. IVMs occur more frequently in women, with an occurrence rate of $25-82 \%$ in published series [12-15]. In our series, no significant female 

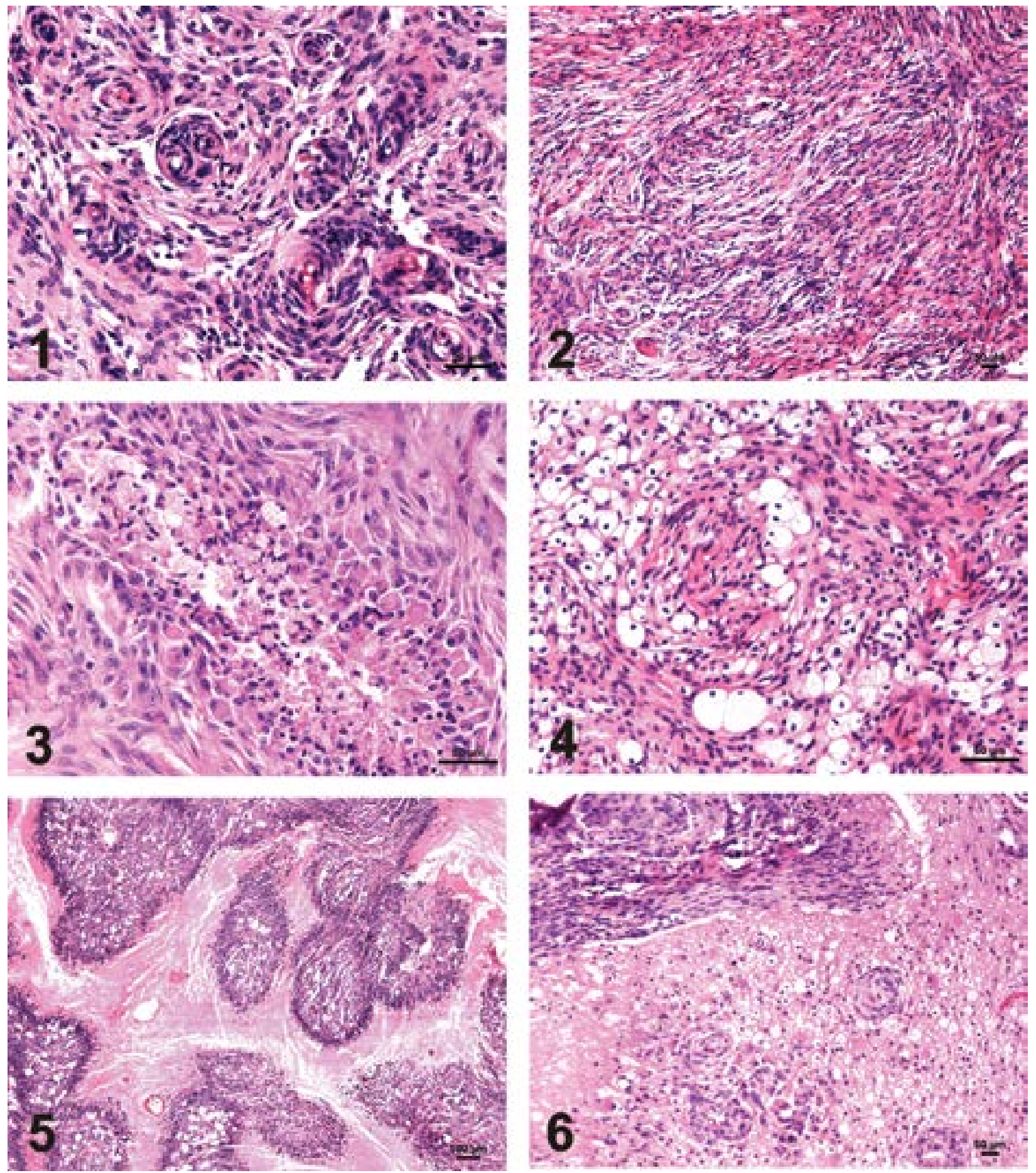

Figure 2.1. Transitional meningioma composed of whorls and cords of neoplastic cells; Figure 2.2. Fibroblastic meningioma consisting of spindle-shaped cells and pericellular collagen; Figure 2.3. Atypical meningioma exhibiting small foci of necrosis with peripheral pseudopalisading; Figure 2.4. Foci of foamy (xanthomatous) cells in atypical meningioma; Figure 2.5. Anaplastic meningioma with large areas of necrosis; Figure 2.6. Neoplastic invasion of the brain parenchyma associated with advanced astroglial reaction

predominance was observed ( $53 \%$ vs $47 \%)$. The mean age reported in the literature varies from 35 to 47 years $[9,16]$; in our study, the mean age was 52 years.
Symptomatology

The most frequent IVM presentations are headaches, nausea, vomiting and visual disturbances, which are reported in 
Table 4. Postoperative complications

\begin{tabular}{|c|c|c|}
\hline & Postoperative complications & $\begin{array}{c}\text { Number } \\
(\%)\end{array}$ \\
\hline \multirow[t]{9}{*}{$\begin{array}{l}\text { Neurological } \\
\text { deficit }\end{array}$} & including: & $6(40 \%)^{*}$ \\
\hline & - deepening of preexisting deficit & $3(20 \%)$ \\
\hline & - new & $5(33 \%)$ \\
\hline & - transient deficit & $4(27 \%)$ \\
\hline & - permanent deficit & $2(13 \%)$ \\
\hline & - aphasia & $1(7 \%)$ \\
\hline & - contralateral paresis & $2(13 \%)$ \\
\hline & - homonymous hemianopsia & $3(20 \%)$ \\
\hline & - confusion, confabulations & $2(13 \%)$ \\
\hline \multirow{3}{*}{$\begin{array}{l}\text { Findings in po- } \\
\text { stoperative } \\
\text { unscheduled }\end{array}$} & - brain oedema & $1(7 \%)$ \\
\hline & - parenchymal haemorrhage & $1(7 \%)$ \\
\hline & - hydrocephalus & 0 \\
\hline \multirow[t]{2}{*}{ CT imaging } & - stroke & 0 \\
\hline & - symptomatic pneumocephalus & 0 \\
\hline CSF leak & & $1(7 \%)$ \\
\hline $\begin{array}{l}\text { Healing prob- } \\
\text { lems }\end{array}$ & & $1(7 \%)$ \\
\hline $\begin{array}{l}\text { General compli- } \\
\text { cations }\end{array}$ & - deep vein thrombosis & $1(7 \%)$ \\
\hline
\end{tabular}

Table 5. New postoperative or deepening of preexisting neurological deficit depending on surgical approach

\begin{tabular}{|c|c|}
\hline $\begin{array}{l}\text { Surgical approach } \\
\text { (No) }\end{array}$ & $\begin{array}{l}\text { Postoperative neurological deficit } \\
\text { No }(\%)\end{array}$ \\
\hline $\begin{array}{l}\text { Transparietal (supe- } \\
\text { rior lobule) (No6) }\end{array}$ & $\begin{array}{l}\text { 5 (83\%) including: } \\
\text { 1. new homonymous hemianopsia - } \\
\text { transient } \\
\text { 2. new contralateral paresis - permanent } \\
\text { 3. deepening of aphasia, new; confusion } \\
\text { - transient } \\
\text { 4. new contralateral paresis - transient } \\
\text { 5. deepening of homonymous hemia- } \\
\text { nopsia and new mild contralateral } \\
\text { paresis - permanent }\end{array}$ \\
\hline Transtemporal (No 7) & $\begin{array}{l}1(14 \%) \\
\text { 1. confusion, confabulations - transient }\end{array}$ \\
\hline Transoccipital (No 2) & 0 \\
\hline
\end{tabular}

$40-80 \%$ of cases. Less common symptoms are mental disturbances, motor deficits, gait and balance disturbances, epilepsy and sensory deficits. In our series, headaches (47\%) was the most common symptom, but only in one case was it the reason for investigation. Frequencies of mental disturbances (40\%), hemianopsia (33\%), papilledema (20\%), hemiparesis $(20 \%)$, gait disturbances (7\%) and epileptic seizures (7\%) (Tab. 1) were similar to other reported series $[9,13-15,17,18]$. Due to their slow growth and specific localisation, intraventricular meningiomas can reach a considerable size, while headaches can occur for up to 15 years before a proper diagnosis is made [19]. The large mean tumour size ( $55 \mathrm{~mm}$ in our series) seems to confirm that these tumours can remain asymptomatic for a long time. This increases the probability of their incidental detection in the current era of widespread neuroimaging diagnostics. In our series, one tumour with a diameter of $66 \mathrm{~mm}$ was detected incidentally following a head injury. On the other hand, headaches without enlargement of the ventricular system (2/7 cases in our group) suggest that, in some cases, unrelated headaches may lead to a diagnosis of an asymptomatic tumour. In the Zanini series, as many as 3/5 tumours were diagnosed incidentally or due to non-specific symptoms [16]. In another series, a large number of IVMs were also detected incidentally [17]. Cerebrospinal fluid flow disorders, and direct pressure on neighbouring structures, have been mentioned as being the cause of the growing symptoms. The rich vascularisation of these tumours can sometimes lead to intralesional or intraventricular haemorrhages with rapid onset of symptoms [20,21].

\section{Characteristics of intraventricular meningiomas}

The most common location of IVMs is the lateral ventricle, followed by the third and fourth ventricle [4]. Nakamura et al. analysed 532 cases of IVMs in publications up to 2003 and found that the frequencies were $77.8 \%, 15.6 \%$ and $6.6 \%$, respectively [15]. In cases of lateral ventricle IVMs, left-side involvement is reported more frequently $[7,14,22]$. In our series, seven meningiomas were located on the left and eight on the right side.

Tumour calcifications in neuroimaging studies in our series were found in $46 \%$ of the patients. In the series of Ma et al., tumour calcifications were visible in $33 \%$ of the CT imaging studies [17]. Calcifications inside the tumour may indicate long-term tumour growth. This could be an argument for the observation of asymptomatic tumours. Interestingly, this option for IVMs has been mentioned [4], although we were unable to identify any reports of IVM observation in the Pubmed database. In the series of Nakamura et al., only 15\% of intraventricular tumours were meningiomas [15].

Therefore, the rarity of intraventricular tumour location, and uncertainty as to its benign nature, favour oncological indications for surgical treatment.

\section{Surgical technique}

The choice of surgical approach to IVMs depends on the tumour size and location. This also includes the direction of the long axis of the tumour and the direction of tumour growth, taking into account the shortest distance to the surface of the brain. The choice of approach is also influenced by existing neurological deficits, by the distance from the tumour to the eloquent structures, and by a desire to minimise brain retraction around the operating corridor. For trigonal IVMs, we 
Table 6. Clinical features and results of surgery in 15 cases of trigone ventricular meningiomas

\begin{tabular}{|c|c|c|c|c|c|c|c|c|c|c|c|}
\hline No & Sex, & & Signs and & Approach & & Tumour & Karnofsk & Performa & Ice Scale & Re- & Follow-up \\
\hline & age & $\begin{array}{c}\text { size } \\
\text { (mm), } \\
\text { side }\end{array}$ & symptoms & & $\begin{array}{l}\text { rative neu- } \\
\text { rological } \\
\text { sequelae }\end{array}$ & $\begin{array}{l}\text { type and } \\
\text { WHO grade }\end{array}$ & $\begin{array}{l}\text { On ad- } \\
\text { mission }\end{array}$ & $\begin{array}{l}\text { At dis- } \\
\text { charge }\end{array}$ & $\begin{array}{l}\text { Most } \\
\text { recent }\end{array}$ & -growth & $\begin{array}{l}\text { period } \\
\text { [years] }\end{array}$ \\
\hline 1 & $M, 72$ & $66, \mathrm{R}$ & accidental & $\begin{array}{l}\text { middle } \\
\text { temporal }\end{array}$ & - & $\begin{array}{l}\text { Transitional, } \\
\text { WHO GI }\end{array}$ & 100 & 100 & 100 & No & 0.5 \\
\hline 2 & $M, 37$ & $65, R$ & headaches & $\begin{array}{l}\text { middle } \\
\text { temporal }\end{array}$ & - & $\begin{array}{c}\text { Transitional, } \\
\text { WHO GI }\end{array}$ & 100 & 100 & 100 & No & 3.9 \\
\hline 3 & $F, 22$ & $45, L$ & $\begin{array}{l}\text { headaches, } \\
\text { papilledema }\end{array}$ & $\begin{array}{l}\text { superior } \\
\text { parietal }\end{array}$ & $\begin{array}{l}\text { perma- } \\
\text { nent hemi- } \\
\text { paresis }\end{array}$ & $\begin{array}{l}\text { Fibroblastic, } \\
\text { WHO GI }\end{array}$ & 90 & 90 & 90 & No & 1.6 \\
\hline 4 & $M, 46$ & $30, R$ & $\begin{array}{l}\text { headaches, } \\
\text { mental distur- } \\
\text { bances, }\end{array}$ & $\begin{array}{l}\text { middle } \\
\text { temporal }\end{array}$ & - & $\begin{array}{l}\text { Transitional, } \\
\text { WHO GI }\end{array}$ & 90 & 100 & 100 & No & 8.2 \\
\hline 5 & $M, 63$ & $56, R$ & $\begin{array}{c}\text { hemiaesthesia, } \\
\text { hemianopsia }\end{array}$ & $\begin{array}{l}\text { superior } \\
\text { parietal }\end{array}$ & $\begin{array}{l}\text { perma- } \\
\text { nent he- } \\
\text { miparesis, } \\
\text { hemia- } \\
\text { nopsia }\end{array}$ & $\begin{array}{c}\text { Atypical, } \\
\text { WHO G II } \\
>\text { Anaplastic, } \\
\text { G III* }\end{array}$ & 90 & 70 & $80>50^{*}$ & Yes & 1.2 \\
\hline 6 & $F, 58$ & $58, \mathrm{~L}$ & $\begin{array}{l}\text { mental distur- } \\
\text { bances }\end{array}$ & $\begin{array}{l}\text { inferior } \\
\text { temporal }\end{array}$ & - & $\begin{array}{l}\text { Transitional, } \\
\text { WHO GI }\end{array}$ & 100 & 100 & $\begin{array}{l}100> \\
100^{*}\end{array}$ & Yes & 20.3 \\
\hline 7 & $M, 47$ & $100, \mathrm{~L}$ & $\begin{array}{l}\text { hemianopsia, } \\
\text { aphasia }\end{array}$ & $\begin{array}{l}\text { superior } \\
\text { parietal }\end{array}$ & $\begin{array}{l}\text { transient } \\
\text { deepening } \\
\text { of aphasia, } \\
\text { confusion }\end{array}$ & $\begin{array}{l}\text { Atypical, } \\
\text { WHO G II }\end{array}$ & 80 & 90 & 90 & No & 0.5 \\
\hline 8 & $\mathrm{~F}, 65$ & $53, \mathrm{~L}$ & $\begin{array}{l}\text { headache, } \\
\text { mental } \\
\text { disturbances, } \\
\text { hemiparesis, } \\
\text { aphasia }\end{array}$ & $\begin{array}{l}\text { superior } \\
\text { parietal }\end{array}$ & - & $\begin{array}{l}\text { Transitional, } \\
\text { WHO GI }\end{array}$ & 70 & 80 & 100 & No & 11.7 \\
\hline 9 & $F, 72$ & $44, R$ & hemiparesis & $\begin{array}{l}\text { superior } \\
\text { parietal }\end{array}$ & $\begin{array}{l}\text { transient } \\
\text { hemia- } \\
\text { nopsia }\end{array}$ & $\begin{array}{l}\text { Fibroblastic, } \\
\text { WHO GI }\end{array}$ & 70 & 70 & 100 & No & 6.2 \\
\hline 10 & $F, 30$ & $60, \mathrm{~L}$ & $\begin{array}{l}\text { headache, he- } \\
\text { mianopsia }\end{array}$ & $\begin{array}{l}\text { superior } \\
\text { parietal }\end{array}$ & $\begin{array}{l}\text { transient } \\
\text { mild hemi- } \\
\text { paresis }\end{array}$ & $\begin{array}{l}\text { Atypical, } \\
\text { WHO G II }\end{array}$ & 90 & 100 & 100 & $\mathrm{~N} / \mathrm{A}$ & $\mathrm{N} / \mathrm{A}$ \\
\hline 11 & $M, 43$ & $35, \mathrm{~L}$ & $\begin{array}{l}\text { epilepsy, he- } \\
\text { mianopsia }\end{array}$ & occipital & - & $\begin{array}{l}\text { Fibroblastic, } \\
\text { WHO GI }\end{array}$ & 90 & 100 & 100 & No & 12,1 \\
\hline 12 & $F, 64$ & $64, R$ & $\begin{array}{l}\text { headache, pa- } \\
\text { pilledema }\end{array}$ & $\begin{array}{l}\text { middle } \\
\text { temporal }\end{array}$ & $\begin{array}{l}\text { transient } \\
\text { confabula- } \\
\text { tions }\end{array}$ & $\begin{array}{c}\text { Angioma- } \\
\text { tous, } \\
\text { WHO GI }\end{array}$ & 90 & 100 & 100 & No & 0.8 \\
\hline 13 & $F, 30$ & $44, R$ & $\begin{array}{c}\text { headache, } \\
\text { mental distur- } \\
\text { bances, gait } \\
\text { disturbances }\end{array}$ & $\begin{array}{l}\text { middle } \\
\text { temporal }\end{array}$ & - & $\begin{array}{l}\text { Transitional, } \\
\text { WHO GI }\end{array}$ & 80 & 100 & 100 & No & 0.5 \\
\hline 14 & $F, 52$ & $45, \mathrm{~L}$ & $\begin{array}{c}\text { mental } \\
\text { disturbances, } \\
\text { papilledema, } \\
\text { hemiaesthesia }\end{array}$ & $\begin{array}{l}\text { inferior } \\
\text { temporal }\end{array}$ & - & $\begin{array}{l}\text { Fibroblastic, } \\
\text { WHO GI }\end{array}$ & 60 & 80 & 100 & No & 1.8 \\
\hline 15 & $M, 78$ & $63, R$ & $\begin{array}{l}\text { mental } \\
\text { disturbances, } \\
\text { hemiparesis, } \\
\text { hemianopsia }\end{array}$ & occipital & - & $\begin{array}{l}\text { Fibroblastic, } \\
\text { WHO GI }\end{array}$ & 90 & 90 & 100 & No & 1.8 \\
\hline
\end{tabular}

*after revision surgery; $\mathrm{F}-$ female; $\mathrm{G}$ - grade; $\mathrm{L}-$ left; $\mathrm{M}-$ male; $\mathrm{N} / \mathrm{A}-$ not available; $\mathrm{R}-$ right 
used transcortical approaches through the posterior temporal lobe, the parietal lobe or the occipital lobe. However, other options, including transsulcal approaches, have also been employed $[17,23]$. The routes through the posterior temporal and occipital lobes increase the risk of quadrantanopsia and hemianopsia. Nevertheless, these routes are often the shortest paths to the tumour and they make possible earlier control of the feeding vessels. The approach through the temporal lobe is also linked to a risk of damage to the vein of Labbe, and - if the tumour is located in the dominant hemisphere - aphasia. In two of our patients, the tumour was reached through the posterior part of the lower temporal gyrus. The transoccipital route was employed in two patients presenting with hemianopsia and with tumours progressing towards the occipital horn. Interestingly, a significant withdrawal of visual field narrowing was observed in both patients in long-term follow-up. This may indicate that, in the case of posterior horn tumours, the visual path may be significantly displaced. Incision within the upper parietal lobule gives a good insight into the medial and lateral part of the ventricular triangle. The access path to the ventricle runs medially from the fibres of the optic radiation, theoretically reducing the risk of optic pathway damage. However, the risk of apraxia and Gerstmann's syndrome remains [17]. In addition, our experience indicates that even permanent hemianopsia can occur with this approach. On the other hand, the interparietal, intraparietal or parieto-occipital approaches appear to be the most popular to trigonal IVMs $[9,12,14-16,18]$.

\section{Histopathology}

Based on the literature, about $90 \%$ of IVMs are benign tumours, $7-8 \%$ are atypical, and 3\% are anaplastic tumours $[4,17]$. Histopathologically, all subtypes of meningiomas are diagnosed, and fibromatous, fibroblastic, meningothelial and psammomatous are the most common. Pereira et al. in a recent systematic review emphasised that the fibrous subtype constitutes as much as $40 \%$ of all IVMs [4]. In our series, $12(80 \%)$ meningiomas were WHO grade I and three (20\%) meningiomas were atypical, including one with malignant transformation to WHO grade III. In the series of Ødegaard et al., $90 \%$ of IVMs were WHO grade I and, similarly, one of two WHO grade II meningiomas recurred rapidly following surgery as an anaplastic meningioma [9].

\section{Treatment results}

$\mathrm{Ma}$ et al. obtained satisfying long-term outcomes (KPS $80-100$ ) in all 42 patients with available catamnesis [17]. Our results are very similar to other series published after 2000 [9, 26]. Most preoperative and postoperative deficits resolved over time (Tab. 2, 4, 5). In long-term evaluation, including the results of revision surgeries, $13 / 14$ patients with available follow-up data were able to lead a normal life (KPS 90-100).

\section{Complications and tumour recurrence}

Perioperative mortality according to the available literature ranges from $0 \%$ to $42 \%$. However, historically it reached as much as $75 \%$ for the 'en bloc' tumour removal technique [7, 15]. The mortality rate based on a systematic review is $4 \%$ [4]. In the series published since 2003, IVMs have been removed entirely in $95 \%$ of cases, with a total mortality rate of $1.6 \%$, which is close to the results of surgery for convexity meningiomas $[9,12,14,15,17-19]$. In our group, no patient died in the perioperative period. The incidence of other complications varies between $0 \%$ and $60 \%[16,17,24]$, while in our series it was $40 \%$. Most often, this was an increase in, or the occurrence of a new, neurological deficit associated with the operative approach. In our series, a permanent deficit occurred in only two (13\%) patients (Tab. 4 and Tab. 5). The most common complication reported in the literature was hemianopsia in $11 \%$ of patients [9]. The risk of tumour recurrence in larger published series ranges from $0 \%$ to $20 \%[9,12,14-19]$. Our tumour recurrence rate was $13 \%$.

The results of surgery for IVMs, although satisfactory in general, require further improvement by reducing the rate of focal deficits resulting from a surgical approach. Currently, the planning of operative corridors based on functional MR with diffusion tensor imaging is a promising tool to avoid subcortical tract damage [25]. Also, the growing popularity of minimally invasive techniques, such as transsulcal approaches using tubular retractors to deep-seated lesions, gives hope for a further decrease in approach-related morbidity [26].

\section{Conclusion}

Intraventricular meningiomas usually attain large size before diagnosis. $20 \%$ of IVMs in our series was atypical. In our experience, neurological complications were most frequent if a transparietal approach was applied. The results of surgery for trigone IVMs, although satisfactory in general, require further improvement. Modern functional brain mapping should be employed more widely to allow more appropriate approach selection.

Conflict of interest: The authors declare no conflict of interest. Ethical Statement: No approval is required by the ethics committee of our institutions for retrospective analyses of patient records and imaging data.

\section{References}

1. Shaw A. Fibrous tumor in the lateral ventricle of the brain, bony deposits in the arachnoid membrane of the right hemisphere. Transactions of the Pathological Society of London 1853. ; 5: 18-21.

2. M'Dowall TW. Large Calcareous Tumour, Involving Chiefly the Inner and Middle Portions of the Left Temporo-Sphenoidal Lobe, and Pressing upon the Left Crus and Optic Thalamus. Edinb Med J. 1881; 26(12): 1088-1093, indexed in Pubmed: 29647272. 
3. Meningiomas: Their Classification, Regional Behavior, Life History, and Surgical End Results. Archives of Neurology And Psychiatry. 1939; 41(3): 657, doi: 10.1001/archneurpsyc.1939.02270150231022.

4. Pereira BJ, de Almeida AN, Paiva WS, et al. Natural history of intraventricular meningiomas: systematic review. Neurosurg Rev. 2018 [Epub ahead of print], doi: 10.1007/s10143-018-1019-0, indexed in Pubmed: 30112665.

5. Jennett B, Bond M. Assessment of outcome after severe brain damage. Lancet. 1975; 1(7905): 480-484, indexed in Pubmed: 46957.

6. Karnofsky D, Burchenal J. The Clinical Evaluation of Chemotherapeutic Agents in Cancer. in: MacLeod C.M. Evaluation of Chemotherapeutic Agents. New York: Columbia University Press. ; 1949: 196-196.

7. Fornari M, Savoiardo M, Morello G, et al. Meningiomas of the lateral ventricles. Neuroradiological and surgical considerations in 18 cases. J Neurosurg. 1981; 54(1): 64-74, doi: 10.3171/jns.1981.54.1.0064, indexed in Pubmed: 7463122.

8. Kloc W, Imieliński BL, Wasilewski W, et al. Meningiomas of the lateral ventricles of the brain in children. Childs Nerv Syst. 1998; 14(8): 350 353, doi: 10.1007/s003810050242, indexed in Pubmed: 9753398.

9. Ødegaard KM, Helseth E, Meling TR. Intraventricular meningiomas: a consecutive series of 22 patients and literature review. Neurosurg Rev. 2013; 36(1): 57-64; discussion 64, doi: 10.1007/s10143-0120410-5, indexed in Pubmed: 22847766.

10. Byard RW, Bourne AJ, Clark B, et al. Clinicopathological and radiological features of two cases of intraventricular meningioma in childhood. Pediatr Neurosci. 1989; 15(5): 260-264, indexed in Pubmed: 2488954.

11. Mircevski M, Mircevska D, Bojadziev I, et al. Surgical treatment of intraventricular meningiomas in childhood. Acta Neurochir Suppl (Wien). 1985; 35: 89-91, indexed in Pubmed: 3867264.

12. Bhatoe HS, Singh P, Dutta V. Intraventricular meningiomas: a clinicopathological study and review. Neurosurg Focus. 2006; 20(3): E9, indexed in Pubmed: 16599425.

13. Criscuolo GR, Symon L. Intraventricular meningioma. A review of 10 cases of the National Hospital, Queen Square (1974-1985) with reference to the literature. Acta Neurochir (Wien). 1986; 83(3-4): 83-91, indexed in Pubmed: 3492867.

14. Liu M, Wei Y, Liu Y, et al. Intraventricular meninigiomas: a report of 25 cases. Neurosurg Rev. 2006; 29(1): 36-40, doi: 10.1007/s10143005-0418-1, indexed in Pubmed: 16220350.

15. Nakamura M, Roser F, Bundschuh 0 , et al. Intraventricular meningiomas: a review of 16 cases with reference to the literature. Surg Neurol. 2003; 59(6): 491-503; discussion 503, indexed in Pubmed: 12826353.
16. Zanini MA, Faleiros AT, Almeida CR, et al. Trigone ventricular meningiomas: surgical approaches. Arq Neuropsiquiatr. 2011; 69(4): 670-675, indexed in Pubmed: 21877039.

17. Ma J, Cheng L, Wang G, et al. Surgical management of meningioma of the trigone area of the lateral ventricle. World Neurosurg. 2014; 82(5): 757-769, doi: 10.1016/j.wneu.2014.05.026, indexed in Pubmed: 24878623.

18. Bertalanffy A, Roessler $\mathrm{K}$, Koperek 0 , et al. Intraventricular meningiomas: a report of 16 cases. Neurosurg Rev. 2006; 29(1): 30-35, doi: 10.1007/s10143-005-0414-5, indexed in Pubmed: 16184406.

19. Lyngdoh BT, Giri PJ, Behari S, et al. Intraventricular meningiomas: a surgical challenge. J Clin Neurosci. 2007; 14(5): 442-448, doi: 10.1016/j.jocn.2006.01.005, indexed in Pubmed: 17350844.

20. $\mathrm{Fu} \mathrm{Z}, \mathrm{Xu} \mathrm{K}, \mathrm{XuB}$, et al. Lateral ventricular meningioma presenting with intraventricular hemorrhage: a case report and literature review. Int J Med Sci. 2011; 8(8): 711-716, indexed in Pubmed: 22135618.

21. Romeike BFM, Joellenbeck B, Skalej M, et al. Intraventricular meningioma with fatal haemorrhage: clinical and autopsy findings. Clin Neurol Neurosurg. 2007; 109(10): 884-887, doi: 10.1016/j.clineuro.2007.07.016, indexed in Pubmed: 17764829.

22. Guidetti B, Delfini R, Gagliardi FM, et al. Meningiomas of the lateral ventricles. Clinical, neuroradiologic, and surgical considerations in 19 cases. Surg Neurol. 1985; 24(4): 364-370, indexed in Pubmed: 3875905.

23. Kawashima M, Li X, Rhoton AL, et al. Surgical approaches to the atrium of the lateral ventricle: microsurgical anatomy. Surg Neurol. 2006; 65(5): 436-445, doi: 10.1016/j.surneu.2005.09.033, indexed in Pubmed: 16630901.

24. Menon G, Nair S, Sudhir J, et al. Meningiomas of the lateral ventricle - a report of 15 cases. Br J Neurosurg. 2009; 23(3): $297-$ 303, doi: 10.1080/02688690902721862, indexed in Pubmed: 19533463.

25. Frati A, Pesce A, D'Andrea G, et al. A purely functional Imaging based approach for transcortical resection of lesion involving the dominant atrium: Towards safer, imaging-guided, tailored cortico-leucotomies. J Clin Neurosci. 2018; 50: 252-261, doi: 10.1016/j.jocn.2018.01.045, indexed in Pubmed: 29429789.

26. Eliyas JK, Glynn R, Kulwin CG, et al. Minimally Invasive Transsulcal Resection of Intraventricular and Periventricular Lesions Through a Tubular Retractor System: Multicentric Experience and Results. World Neurosurg. 2016; 90: 556-564, doi: 10.1016/j.wneu.2015.12.100, indexed in Pubmed: 26805678. 